\title{
PENERAPAN MODEL PEMBELAJARAN DIRECT INSTRUCTION DILENGKAPI APLIKASI BUKU SAKU BERBASIS ANDROID UNTUK MENINGKATKAN KEMANDIRIAN SISWA DAN PRESTASI BELAJAR DALAM MATERI STOIKIOMETRI KELAS X MIA 2 SMA BATIK 2 SURAKARTA TAHUN AJARAN 2016/2017
}

\author{
Novian Setiani, Haryono*, dan Agung Nugroho CS \\ Program Studi Pendidikan Kimia, FKIP,Universitas Sebelas Maret, Surakarta, Indonesia \\ Keperluan korespodensi, telp : 08122624628, email : hharyono52@yahoo.com
}

\begin{abstract}
ABSTRAK
Penelitian ini bertujuan untuk meningkatkan kemandirian dan prestasi belajar siswa kelas X MIA 2 SMA Batik 2 Surakarta Tahun Pelajaran 2016/2017 melalui penerapan model pembelajaran direct instruction dilengkapi aplikasi buku saku berbasis android pada materi stoikiometri. Penelitian ini merupakan Penelitian Tindakan Kelas (PTK) yang dilaksanakan dalam dua siklus. Setiap siklusnya terdapat empat tahapan yang terdiri dari perencanaan tindakan, pelaksanaan tindakan, observasi, dan refleksi. Subjek penelitian adalah siswa kelas X MIA 2 SMA Batik 2 Surakarta Tahun Pelajaran 2016/2017. Sumber data adalah siswa, guru, dan peristiwa atau kegiatan siswa. Teknik pengumpulan data melalui observasi, wawancara, angket penilaian diri, dan tes. Teknik analisis yang digunakan dalam penelitian ini adalah analisis kualitatif. Berdasarkan hasil penelitian dapat disimpulkan bahwa penerapan model pembelajaran direct instruction dapat meningkatkan kemandirian dan prestasi belajar siswa pada materi stoikiometri kelas X MIA 2 SMA Batik 2 Surakarta tahun pelajaran 2016/2017. Pada siklus I masing-masing persentase ketercapaian kemandirian siswa, prestasi belajar aspek pengetahuan, aspek sikap dan aspek keterampilan yaitu $86,11 \% ; 50 \% ; 88,89 \%$ dan $100 \%$. Setelah diberikan tindakan pada siklus II, masing-masing persentase ketercapaian kemandirian siswa, prestasi belajar aspek pengetahuan, dan aspek sikap meningkat menjadi $91,67 \% ; 72,20 \%$ dan $94,44 \%$. Prestasi belajar aspek keterampilan hanya dilakukan pada siklus I karena target yang ditentukan telah tercapai.
\end{abstract}

Kata kunci : Direct Instruction, aplikasi buku saku, kemandirian, prestasi belajar, stoikiometri

\section{PENDAHULUAN}

Pada zaman globalisasi seperti sekarang ini, pendidikan merupakan masalah yang penting bagi setiap bangsa. Pendidikan merupakan salah satu parameter tingkat peradaban bangsa. Melalui pendidikan yang berkualitas dapat meningkatkan kualitas sumber daya manusia (SDM) sehingga mampu mengelola sumber daya alam secara efektif dan efisien. Menurut PISA (Programme for International Student Assesment) Indonesia berada di 10 besar terbawah dari 65 negara peserta PISA [1]. Hal ini menunjukkan bahwa kualitas pendidikan di Indonesia masih rendah.
Salah satu langkah pemerintah untuk memperbaiki kualitas pendidikan di Indonesia yaitu dengan adanya perubahan kurikulum. Menurut Undangundang Nomor 20 Tahun 2003 tentang Sistem Pendidikan Nasional Pasal 1 butir 19, kurikulum adalah seperangkat rencana dan pengaturan mengenai tujuan, isi, dan bahan pelajaran serta cara yang digunakan sebagai pedoman penyelenggaraan kegiatan pembelajaran untuk mencapai tujuan pendidikan tertentu. Pada Tahun 2013 di Indonesia terjadi perubahan kurikulum dari Kurikulum Tingkat Satuan pendidikan (KTSP) menjadi Kurikulum 2013.

$$
\text { Kurikulum } 2013 \text { merupakan }
$$
pengembangan dari kurikulum tingkat 
satuan pendidikan (KTSP). Pada kurikulum 2013 penataan Standar Nasional Pendidikan (SNP) lebih menekankan pada standar kompetensi lulusan (SKL), standar isi, standar proses, dan standar penilaian. Berdasarkan Peraturan Menteri Pendidikan dan Kebudayaan Republik Indonesia (Permendikbud RI) No.54 Tahun 2013 Tentang Standar Kompetensi Lulusan (SKL) menyebutkan kriteria kualifikasi kemampuan siswa yang diharapkan dapat dicapai setelah menyelesaikan masa belajarnya pada jenjang pendidikan menengah meliputi sikap, pengetahuan, dan ketrampilan. Dengan diterapkannya kurikulum 2013 diharapkan dapat meningkatkan sumber daya manusia yang kreatif, produktif, inovatif, dan memiliki pengetahuan yang terintegrasi.

SMA Batik 2 Surakarta merupakan salah satu sekolah swasta yang berada di kota Surakarta yang telah menerapkan kurikulum 2013. Berdasarkan hasil ujian nasional mata pelajaran kimia Tahun ajaran 2015/2016 SMA Batik 2 Surakarta masih memiliki kualitas pendidikan yang cukup rendah. Selain itu brdasarkan hasil observasi cara mengajar guru di SMA Batik 2 Surakarta didapatkan bahwa dalam pelajaran kimia guru masih dominan yaitu dengan menggunakan model pembelajaran Teacher Centered Learning (TCL) dimana proses pembelajaran berlangsung satu arah sehingga siswa masih belum aktif mengembangkan kemampuannya. SMA Batik 2 Surakarta memiliki 3 kelas MIA, yaitu X MIA 1, X MIA 2, dan X MIA 3. Diantara ketiga kelas tersebut prestasi belajar siswa yang apling rendah terdapat di kelas X MIA 2. Hal ini terbukti dari ketuntasan siswa yang hanya mencapai 15\%-20\%.

Berdasarkan hasil observasi di SMA Batik 2 Surakarta ketika siswa diberi tugas individu, siswa masih mengandalkan teman di kelas untuk mengerjakan tugas tersebut dan siswa cenderung untuk selalu bertanya kepada temannya. Hal ini menunjukkan bahwa siswa cenderung bergantung kepada temannya. Selain itu ketika siswa diberikan pekerjaan rumah (PR) mayoritas siswa tidak mengerjakan tugas tersebut,dan ketika siswa diminta untuk memperlajari materi yang akan diajarkan guru maka mayoritas siswa tidak mempelajarinya hal ini menunjukkan inisiatif siswa dalam mempelajari ilmu kimia masih cukup rendah, selain itu siswa juga masih belum bebas, belum bebas disini memiliki arti siswa belum tumbuhnya tindakan atas kehendak sendiri dan masih bergantung pada orang lain. Kepercayaan diri siswa juga masih rendah, hal ini terbukti ketika ulangan harian siswa masih banyak yang bertanya kepada temannya. Dari ciri-ciri diatas dapat disimpulkan bahwa kemandirian siswa masih rendah.

Salah satu mata pelajaran wajib bagi siswa kelas $X$ yaitu mata pelajaran kimia. Ilmu kimia juga mempelajari tentang zat-zat kimia yang bermanfaat bagi kehidupan manusia. Kesulitan pembelajaran kimia terletak pada kesenjangan yang terjadi antara pemahaman konsep dan penerapan konsep yang ada, sehingga menimbulkan asumsi sulit untuk mempelajari dan mengembangkan [2]. Berdasarkan hasil wawancara dengan guru kimia, materi kimia yang dianggap sulit oleh siswa kelas X MIA pada semester genap yaitu stoikiometri. Stoikiometri adalah ilmu yang mempelajari kuantitas dari reaktan dan produk dalam reaksi kimia [3].

Karakteristik materi stoikiometri yaitu berisi konsep-konsep, hukumhukum, dan rumus-rumus perhitungan dasar kimia dengan berbagai hubungan sehingga perlu banyak latihan dalam mempelajarinya agar konsep, hukum, dan rumus tersebut tidak mudah hilang dalam ingatan [4]. Ausubel (1968) menyatakan bahwa bahwa belajar bermakna merupakan suatu proses dikaitkannya informasi baru pada konsep-konsep yang relevan yang terdapat dalam struktur kognitif seseorang. Berdasarkan pendapat Ausubel diatas maka siswa cenderung mencocokan informasi yang baru ia dapatkan dengan informasi yang ia telah miliki sebelumnya. Namun pada siswa SMA materi stoikiometri itu hal baru yang sebelumnya tidak pernah didapatkan oleh siswa, oleh karena itu siswa 
mengalami kesulitan belajar pada materi tersebut.

Menurut Piaget perkembangan kognitif merupakan suatu perkembangan genetika yaitu proses yang didasarkan atas mekanisme biologis yaitu sistem syaraf. Pertambahan umur diikuti pula oleh pertumbuhan sistem syaraf yang kompleks dan memungkinkan kemampuan seseorang meningkat. Dengan demikian proses belajar akan mengikuti pola dan tahap perkembangan sesuai umurnya. Seseorang tidak akan mampu mempelajari sesuatu diluar kemampuan kognitifnya [5].

Menurut Gagne (1970) ada 8 tipe belajar yang membentuk suatu hierarki dari paling sederhana sampai paling kompleks.Berdasarkan hal tersebut maka pembelajaran harus bertahap sehingga dapat mengatasi kesulitan belajar pada siswa. Inovasi pembelajaran dengan pemberian materi secara bertahap disertai dengan bimbingan diyakini dapat memudahkan siswa dalam mempelajari materi stoikiometri. Salah satu model yang sesuai untuk mengatasi permasalahan proses belajar mengajar di atas yaitu model pembelajaran Direct Instruction (DI). Arends mengungkapkan bahwa model pengajaran langsung adalah salah satu pendekatan mengajar yang dirancang khusus untuk menunjang proses belajar siswa yang berkaitan dengan pengetahuan deklaratif dan pengetahuan prosedural yang terstruktur dengan baik yang dapat diajarkan dengan pola kegiatan yang bertahap, selangkah demi selangkah [6]. Direct Instruction atau pengajaran langsung dirancang untuk meningkatkan penguasaan berbagai ketrampilan (pengetahuan prosedural) dan pengetahuan faktual yang dapat diajarkan secara langkah demi langkah atau bertahap,oleh karena itu model pengajaran langsung dapat digunakan untuk mengatasi kesulitan belajar siswa pada materi pokok stoikiometri.

Untuk memudahkan siswa dalam memahami konsep di dalam stoikiometri dapat digunakan media pembelajaran. Media pembelajaran adalah sumbersumber belajar selain guru yang dijadikan sebagai penyalur atau penghubung pesan ajar yang diadakan dan/atau diciptakan secara terencana oleh guru atau pendidik [7] . Media dalam proses belajar mengajar mempunyai peran yang penting karena media sebagai alat perantara dalam kegiatan belajar mengajar. Media pembelajaran dapat digunakan siswa sebagai salah satu sumber belajar. Sumber belajar yang paling sering digunakan oleh siswa dan guru adalah buku pelajaran. Salah satu media pembelajaran yang dapat digunakan yaitu media aplikasi buku saku berbasis android. Media ini dapat memudahkan siswa untuk belajar materi stoikiometri karena bentuknya yang praktis dan berada di smartphone siswa sehingga siswa dengan mudah dapat membukanya setiap saat.

\section{METODE PENELITIAN}

Penelitian ini merupakan Penelitian Tindakan Kelas (PTK) yang dilaksanakan dalam dua siklus. Setiap siklusnya terdapat empat tahapan, yaitu perencanaan, pelaksanaan, observasi, dan refleksi. Subjek penelitian adalah siswa kelas X MIA 2 SMA Batik 2 Surakarta tahun pelajaran 2016/2017. Pemilihan subjek dalam penelitian ini didasarkan pada hasil observasi yang dilakukan pada saat prasiklus, dimana subjek yang dipilih tersebut teridentifikasi mempunyai permasalahan dalam pembelajaran yaitu kemandirian dan prestasi belajar yang rendah.

Data yang dikumpulkan meliputi data kemandirian siswa dan prestasi belajar siswa yang mencakup aspek pengetahuan, aspek sikap, dan aspek keterampilan baik pada siklus I maupun siklus II.

Analisis data menggunakan tiga tahap yaitu reduksi data (pengelolaan data), penyajian data (mengorganisasikan data kedalam suatu bentuk tertentu sehingga datanya terlihat lebih utuh), dan triangulasi atau pemeriksaan keabsahan data dengan memanfaatkan sesuatu yang lain di luar data tersebut sebagai pembanding data [8]. 


\section{HASIL DAN PEMBAHASAN}

Hasil dari observasi kegiatan pembelajaran di kelas, wawancara, dan kajian dokumen menunjukkan bahwa aspek kemandirian sudah cukup baik dan prestasi belajar siswa masih tergolong rendah pada materi stoikiometri. Selain itu, dalam proses pembelajaran keterlibatan siswa belum diterapkan secara maksimal atau pembelajaran belum berpusat pada siswa sehingga proses pembelajaran belum berjalan efektif.

\section{Siklus I}

\section{a. Perencanaan}

Pada tahap perencanaan siklus I dilakukan penyusunan silabus, RPP, aplikasi buku saku, instrumen penilaian kemandirian, serta instrumen prestasi belajar. Berdasarkan data silabus diketahui bahwa materi stoikiometri memiliki alokasi waktu 8 jam pelajaran (8 jp). Perincian pembelajaran pada siklus I yaitu 6 jp $\left(\begin{array}{lllll}6 & \times & 45 & \text { menit }) & \text { untuk }\end{array}\right.$ penyampaian materi dan 2 jp $(2 \times 45$ menit) untuk evaluasi siklus I.

\section{b. Pelaksanaan}

Tahap pelaksanaan siklus I terdiri atas 5 kali pertemuan, dengan 4 kali pertemuan untuk penyampaian materi dan 1 kali pertemuan untuk evaluasi siklus I. Pada pertemuan awal ini guru memulai pembelajaran dengan materi konsep mol. Pembelajaran diawali dengan guru memberikan apersepsi dan menjelaskan tujuan serta manfaat pembelajaran yang akan dilakukan. Setelah itu guru menjelaskan materi konsep mol dan memberikan kesempatan kepada siswa untuk bertanya, selanjutnya memberikan contoh soal untuk dikerjakan bersama. Setelah itu siswa diberikan latihan soal yang telah diperluas untuk dikerjakan dengan berdiskusi. Hasil diskusi kemudian dipresentasikan di depan kelas. Pembelajaran ditutup dengan menarik kesimpulan pembelajaran secara bersama-sama, selanjutnya guru memberikan soal keterampilan dan tindak lanjut berupa pos tes.

Pertemuan kedua, ketiga dan keempat secara teknis hampir sama dengan pertemuan pertama, hanya saja pada pertemuan tersebut materi pembelajaran yang disampaikan berbeda. Pada pertemuan terakhir atau pertemuan kelima, dilaksanakan evaluasi siklus I yang meliputi penilaian aspek pengetahuan dimana siswa harus menjawab soal ulangan dan waktu yang tersisa digunakan untuk mengisi angket penilaian diri kemandirian dan aspek sikap.

\section{c. Pengamatan}

Analisis hasil tes pada siklus I dapat dibuat dalam beberapa kategorikategori. Hasil penilaian kemandirian siswa dapat dibuat kategori seperti pada Gambar 1.

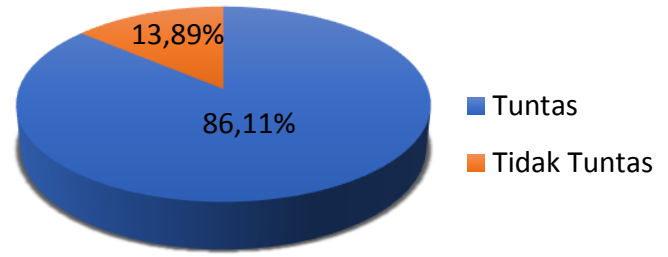

Gambar 1. Ketercapaian Aspek Kemandirian Siswa Siklus I

Gambar 1 merepresentasikan aspek kemandirian siswa telah mencapai ketuntasan sebesar 86,1\%. Ketuntasan penilaian aspek kemandirian baik melalui angket maupun penilaian observasi sudah mencapai target yaitu lebih dari $75 \%$. Adapun keempat indikator aspek kemandirian yaitu motivasi siswa, kedisiplinan belajar siswa, inisiatif siswa, tanggung jawab siswa dan perpaduan seluruhnya sudah tuntas pada siklus I. Siklus II dilaksanakan untuk mengetahui peningkatan kemandirian siswa.

Hasil penilaian aspek pengetahuan menunjukkan bahwa $50 \%$ siswa yang tuntas dan $50 \%$ siswa belum mencapai KKM atau masih di bawah target siklus I yaitu $65 \%$. Hasil siklus I terdapat 1 indikator yang belum memenuhi target dan 6 indikator yang yang sudah memenuhi target. Rendahnya ketuntasan aspek pengetahuan dikarenakan siswa lupa apabila konversi mol menjadi partikel massa harus dikalikan bilangan $6.02 \times 10^{23}$. Kemudian, pada beberapa siswa yang mengingat bilangan tersebut, 
siswa mengalami kesulitan dalam perhitungan bilangan desimal yang berpangkat.

Hasil penilaian aspek sikap siswa dapat dilihat pada Gambar 3.

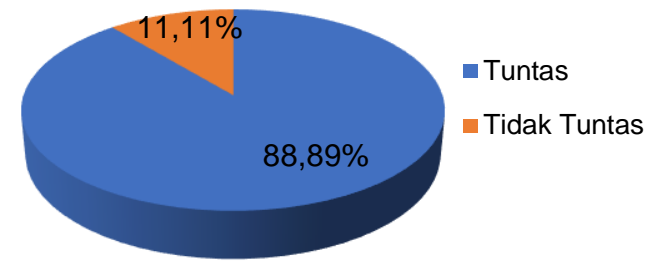

Gambar 3. Penilaian Aspek Sikap Siswa Siklus I.

Gambar 3 menunjukkan jika ketuntasan aspek sikap sebesar 88,89\%. Ketuntasan yang diperoleh merupakan akumulasi persentase siswa kategori baik dan sangat baik. Capaian hasil aspek sikap siswa sudah mencapai target yang ditentukan yaitu $75 \%$. Ketuntasan indikator sikap sudah mencapai target yaitu aspek percaya diri spiritual, jujur dan disiplin.

Hasil observasi menunjukkan penilaian aspek keterampilan menunjukan bahwa seluruh siswa telah tuntas. Pada aspek keterampilan telah memenuhi target yang ditentukan yaitu $75 \%$ siswa yang tuntas.

\section{d. Refleksi}

Hasil pengamatan yang dilakukan menunjukkan masih terdapat aspek yang belum mencapai target yaitu aspek pengetahuan siswa. Oleh karena itu, perlu dilaksanakan siklus II yang diharapkan dapat meningkatkan prestasi belajar siswa sehingga mencapai target yang sudah ditentukan.

\section{Siklus II}

\section{a. Perencanaan}

Pada pelaksanaan siklus II ini lebih difokuskan untuk perbaikan terhadap kendala-kendala yang muncul pada siklus I. Materi yang diberikan juga fokus pada indikator-indikator yang belum mencapai ketuntasan yaitu Mengkonversi jumlah mol dengan jumlah partikel massa dan volume zat. Pada evaluasi siklus II semua indikator diujikan untuk mengetahui peningkatannya. Pemberian bimbingan oleh guru lebih terfokus pada siswa yang belum tuntas.

\section{b. Pelaksanaan}

Siklus II ini dilaksanakan dalam 2 kali pertemuan, yaitu 1 kali pertemuan untuk penyampaian materi dan 1 kali pertemuan untuk evaluasi siklus II.

Pada pertemuan pertama, guru membuka pembelajaran dan memberikan apersepsi. Selanjutnya Guru mengulas kembali materi yang belum dipahami siswa yaitu materi Mengkonversi jumlah mol dengan jumlah partikel massa dan volume zat. Guru memberikan kesempatan kepada siswa untuk bertanya bagian yang belum dipahami. Selanjutnya guru memberikan soal latihan untuk dikerjakan oleh siswa. Guru membimbing siswa dalam mengerjakan latihan soal terutama pada siswa yang masih belum tuntas. Selanjutnya siswa diberikan soal yang telah diperluas dan diminta untuk mengerjakannya bersama teman sebangku. Setelah siswa selesai mengerjakan soal, siswa diberikan kesempatan untuk menyampaikan hasil jawaban soal di depan kelas. Selanjutnya guru bersama siswa menyimpulkan kegiatan pembelajaran.

\section{c. Pengamatan}

Hasil observasi dan analisis tes yang sudah dilakukan pada siklus II dapat dilihat hasil analisis kemandirian siswa, prestasi belajar siswa, dan aspek aspek sikap siswa. Hasil observasi dan analisis angket kemandirian siswa dapat dilihat pada Gambar 4.

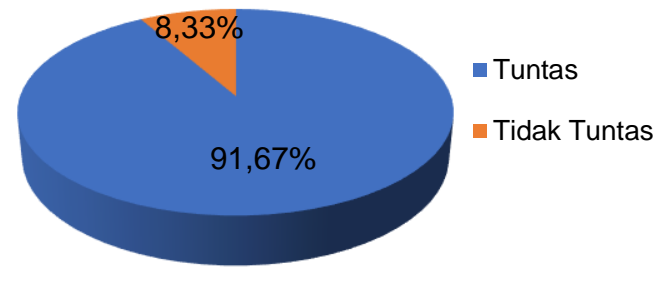

Gambar 4. Penilaian Kemandirian Siklus II 
Hasil yang disajikan pada Gambar 4 menunjukkan ketuntasan kemandirian siswa sebesar 91,67\%. Hasil ini merupakan akumulasi persentasi siswa sangat baik dan baik. ketuntasan yang diperoleh sudah mencapai target yang direncanakan dan semua aspek juga sudah mencapai target sebesar $75 \%$.

Hasil tes aspek pengetahuan siklus II dapat dilihat pada Gambar 5.

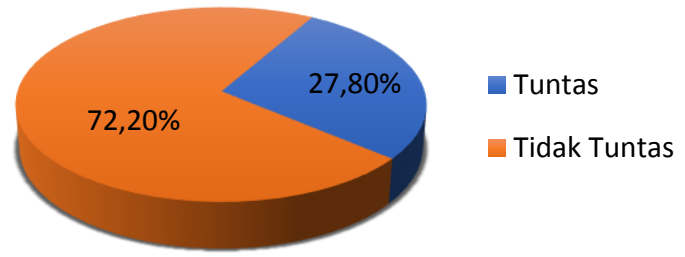

Gambar 5. Penilaian Aspek Pengetahuan siswa Siklus II

Jumlah capaian aspek pengetahuan siklus ini sebesar $72,20 \%$, hasil ini sudah melampaui target sebesar $65 \%$. Semua indikator yang diujikan juga sudah mencapai target yang ditetapkan.

Hasil observasi dan analisis angket aspek sikap siswa dapat dilihat pada Gambar 6.

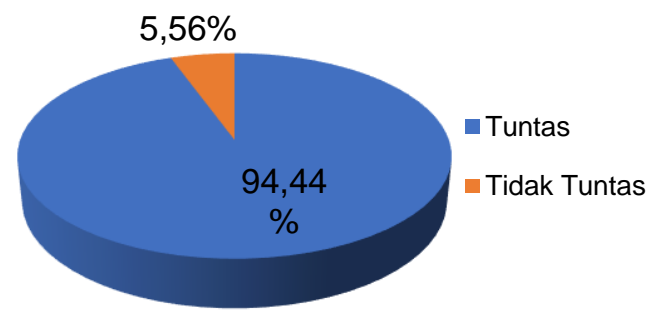

Gambar 6. Penilaian Aspek Sikap Siswa Siklus II

Gambar 6 menunjukkan jika ketuntasan aspek sikap sebesar 94,44\% hal ini menunjukan telah tercapainya target yang ditentukan yaitu $75 \%$. Semua indikator pada aspek sikap juga sudah mencapai target yang ditentukan.

\section{d. Refleksi}

Berdasarkan hasil pengamatan dan evaluasi yang dilaksanakan pada siklus II bahwa semua aspek telah mencapai target yang telah ditetapkan dan terjadi peningkatan pada setiap aspek.

\section{Perbandingan antar Siklus}

Berdasarkan hasil observasi, angket, tes dan wawancara yang telah dilakukan baik disiklus I maupun II dengan menggunkan model pembelajaran direct instruction dengan bantuan aplikasi buku saku maka hasil tersebut dapat dibandingkan untuk mengetahui peningkatan yang terjadi pada setiap penilaian.

Pada siklus II, persentase ketercapian kemandirian siswa mengalami peningkatan dibandingkan dengan hasil siklus I. pada siklus I persentase ketercapian sebesar $86,11 \%$ meningkat menjadi $91,67 \%$ pada siklus II. Hal tersebut terjadi karena persentase siswa kategori sangat baik meningkat diimbangi penurunanan persentase kemandirian kategori baik dan cukup. Ketercapaian kemandirian siswa pada siklus I dan siklus II disajikan pada Gambar 7.

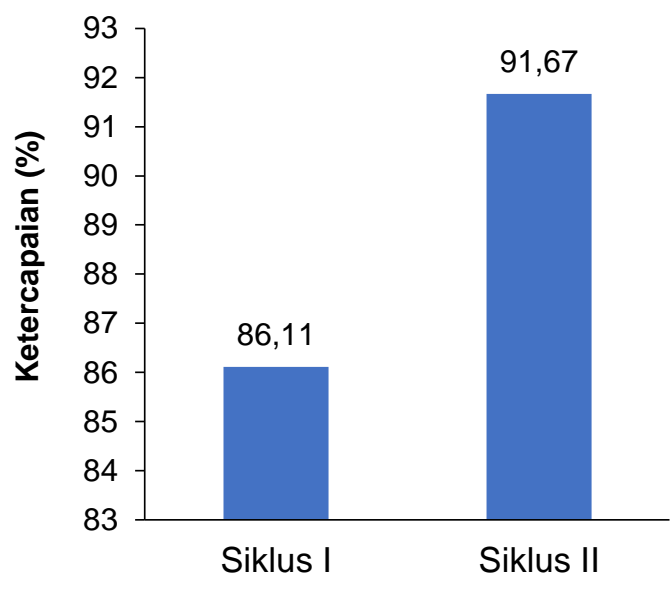

Gambar 7. Diagram Persentase Ketercapaian Kemandirian Siswa pada Siklus I dan II

Prestasi belajar meliputi aspek pengetahuan, aspek sikap, dan aspek keterampilan. Berdasarkan hasil tes pengetahuan pada siklus I dan II, menunjukkan bahwa terjadi peningkatan ketuntasan belajar siswa dari 50\% menjadi $72,20 \%$. Adapun peningkatan aspek pengetahuan siklus I dan siklus II disajikan pada Gambar 8. 


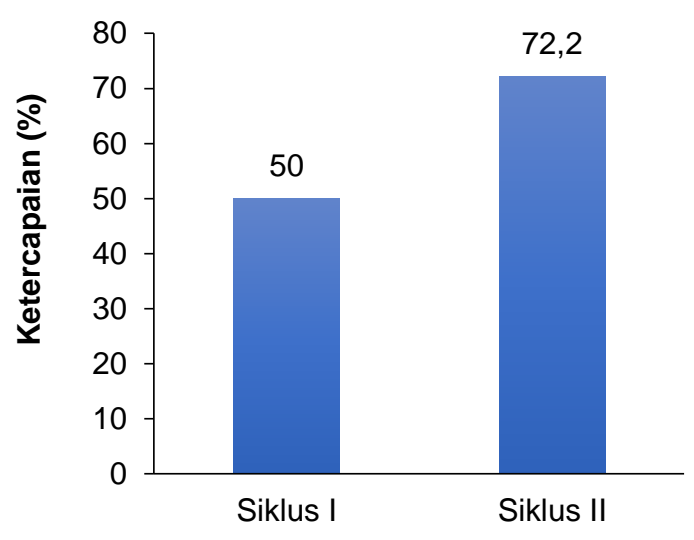

Gambar 8. Diagaram Persentase Ketuntasan Aspek Pengetahuan pada Siklus I dan Siklus II

Pada siklus I pencapaian aspek sikap sebesar $88,89 \%$. Hasil ini sudah memenuhi target yang telah ditentukan yaitu $75 \%$. Pada siklus II persentase ketercapaian aspek sikap meningkat dari pada siklus I menjadi 94,44\%. Hal tersebut terjadi karena siswa kategori sangat baik meningkat dan kategori cukup mengalami penurunanan. Ketercapaian aspek sikap siswa pada siklus I dan siklus II disajikan pada Gambar 9.

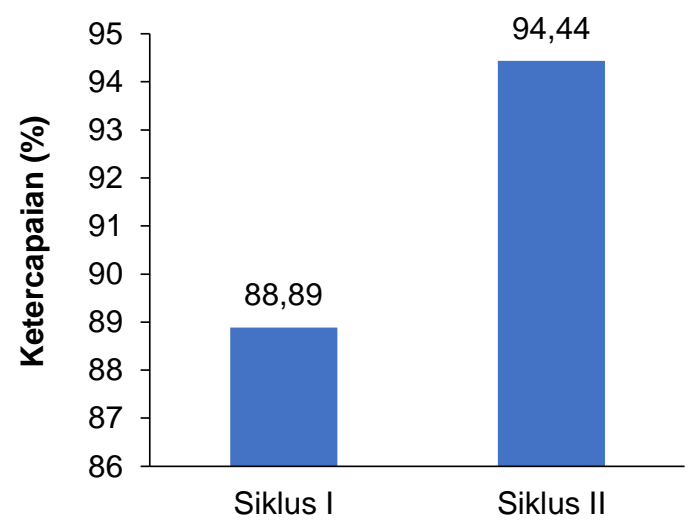

Gambar 9. Diagram Persentase Ketercapaian Sikap Siswa pada Siklus I dan II

Aspek keterampilan pada siklus I didapatkan semua siswa telah tuntas. Hal ini membuat aspek keterampilan tidak dilaksanakan kembali pada siklus II

Berdasarkan hasil tersebut, penelitian dengan menggunakan model pembelajaran direct instruction dengan bantuan aplikasi buku saku dikatakan berhasil karena pada akhir penelitian semua aspek telah mencapai target yang ditetapkan. Penelitian ini dapat mening- katkan proses belajar siswa yaitu kemandirian serta prestasi belajar siswa yang terdiri dari aspek sikap, aspek pengetahuan, dan aspek keterampilan.

\section{KESIMPULAN}

Berdasarkan hasil penelitian yang telah dilakukan, maka dapat disimpulkan bahwa penerapan model pembelajaran Direct Instruction dengan bantuan aplikasi buku saku dapat meningkatkan kemandirian dan prestasi belajar siswa pada materi stoikiometri kelas X MIA 2 SMA Batik 2 Surakarta tahun ajaran 2016/2017.

\section{UCAPAN TERIMA KASIH}

Penelitian ini dapat terselenggara dengan baik atas bantuan dari berbagai pihak. Penulis mengucapkan terimakasih kepada Kepala SMA Batik 2 Surakarta, Bapak Djoko, S.Pd, M.Pd, atas izin yang diberikan kepada penulis untuk melakukan penelitian di sekolah, dan kepada guru kimia kelas $X$ Bapak Ispriyanto, S.Pd, M.Pd. yang telah memberikan izin untuk penelitian di kelas $X$ MIA 2 SMA Batik 2 Surakarta.

\section{DAFTAR RUJUKAN}

[1] Mulyasa. (2014). Pengembangan dan Implementasi Kurikulum 2013. Bandung: PT. Remaja Rosdakarya.

[2] Sugiyono.(2011). Metode Penelitian Pendidikan. Bandung: Alfabeta.

[3] Chang, R. (2005). Kimia Dasar: Konsep - konsep Inti Jilid 1. Terj. Muhamad. Jakarta: Erlangga

[4] Alfian, Zul. (2009). Kimia Dasar. Medan: USU press.

[5] Dahar, R.W. (2011). Teori-teori Belajar dan Pembelajaran. Jakarta: Erlangga.

[6] Arends, Richard. (2007). Learning to Teach. Yogyakarta: Pustaka Pelajar.

[7] Arsyad, Azhar. (2006). Media Pembelajaran. Jakarta: PT. Rajagrafindo. 